\title{
A Fibroblast Growth Factor 21-Pregnane X Receptor Pathway Downregulates Hepatic CYP3A4 in Nonalcoholic Fatty Liver Disease ${ }^{\mathrm{S}}$
}

\author{
Sarah J. Woolsey, Melanie D. Beaton, Sara E. Mansell, Matilde Leon-Ponte, Janice Yu, \\ Christopher L. Pin, Paul C. Adams, Richard B. Kim, and Rommel G. Tirona
}

Department of Physiology and Pharmacology (S.J.W., J.Y., C.L.P., R.B.K., R.G.T), Division of Gastroenterology, Department of Medicine (M.D.B., P.C.A.), Division of Clinical Pharmacology, Department of Medicine (S.J.W., S.E.M., M.L.-P., J.Y., R.B.K., R.G.T.), Department of Paediatrics (C.L.P.), and Department of Oncology (C.L.P., R.B.K.), Schulich School of Medicine and Dentistry, University of Western Ontario, London, Ontario, Canada

Received April 11, 2016; accepted July 28, 2016

\section{ABSTRACT}

Nonalcoholic fatty liver disease (NAFLD) alters drug response. We previously reported that NAFLD is associated with reduced in vivo CYP3A drug-metabolism activity and hepatic CYP3A4 expression in humans as well as mouse and human hepatoma models of the disease. Here, we investigated the role of the lipidand glucose-modulating hormone fibroblast growth factor 21 (FGF21) in the molecular mechanism regulating CYP3A4 expression in NAFLD. In human subjects, mouse and cellular NAFLD models with lower CYP3A4 expression, circulating FGF21, or hepatic FGF21 mRNA levels were elevated. Administration of recombinant FGF21 or transient hepatic overexpression of FGF21 resulted in reduced liver CYP3A4 luciferase reporter activity in mice and decreased CYP3A4 mRNA expression and activity in cultured Huh7 hepatoma cells. Blocking canonical FGF21 signaling by pharmacological inhibition of MEK1 kinase in Huh7 cells caused de-repression of CYP3A4 mRNA expression with FGF21 treatment. Mice with high-fat dietinduced simple hepatic steatosis and lipid-loaded Huh7 cells had reduced nuclear localization of the pregnane $X$ receptor (PXR), a key transcriptional regulator of CYP3A4. Furthermore, decreased nuclear PXR was observed in mouse liver and Huh7 cells after FGF21 treatment or FGF21 overexpression. Decreased PXR binding to the CYP3A4 proximal promoter was found in FGF21-treated Huh7 cells. An FGF21-PXR signaling pathway may be involved in decreased hepatic CYP3A4 metabolic activity in NAFLD.

\section{Introduction}

Nonalcoholic fatty liver disease (NAFLD) is considered the liver manifestation of metabolic syndrome, characterized as triglyceride accumulation within hepatocytes in the absence of significant alcohol consumption (Marchesini et al., 2003). NAFLD affects approximately one-third of the Western adult population, with a high prevalence in obesity and type 2 diabetes (Browning et al., 2004). It is a disease spectrum that includes simple steatosis and nonalcoholic steatohepatitis (NASH), a progressive stage involving inflammation and hepatocyte ballooning. NASH is associated with increased risk for hepatic fibrosis, cirrhosis, and hepatocellular carcinoma (Angulo, 2002).

This research was supported by the Canadian Institutes of Health Research [Grant MOP-136909].

dx.doi.org/10.1124/mol.116.104687

S This article has supplemental material available at molpharm. aspetjournals.org.
Current management strategies for NAFLD, and in particular NASH, focus on weight reduction and pharmacotherapy to treat comorbidities such as hypertension, dyslipidemia, and diabetes. Many medications used by patients with NAFLD are eliminated from the body by the intestinal and hepatic enzyme CYP3A4 (Guengerich, 1999). We reported that in vivo CYP3A activity in subjects with biopsy-proven NAFLD was reduced in both simple steatosis and NASH, and that CYP3A4 mRNA levels were lower in NASH liver biopsies than in normal liver (Woolsey et al., 2015). Furthermore, we found similar reductions in CYP3A4 expression in mouse and cultured human hepatoma models of the disease (Woolsey et al., 2015). However, the underlying molecular mechanisms involved had yet to be determined.

A direct transcriptional regulator of CYP3A4 is the xenosensing nuclear hormone receptor, pregnane $\mathrm{X}$ receptor (PXR) (Kliewer et al., 1998; Tirona et al., 2003). Exposure to PXR-activating dietary and xenobiotic ligands induces hepatic CYP3A4 drug-metabolism activity. Interestingly, PXR is also involved in energy homeostasis, and consequently, PXR

ABBREVIATIONS: ALD, alcoholic liver disease; ELISA, enzyme-linked immunosorbent assay; ER, endoplasmic reticulum; ERK, extracellular signal-regulated kinase; FGF21, fibroblast growth factor 21; FGFR, fibroblast growth factor receptor; GFP, green fluorescence protein; HFD, highfat diet; hFGF21, human fibroblast growth factor 21; hPXR, human pregnane X receptor; MAPK, mitogen-activated protein kinase; NAFLD, nonalcoholic fatty liver disease; NASH, nonalcoholic steatohepatitis; ND, normal diet; PCR, polymerase chain reaction; PD184352, 2-(2-chloro-4iodophenylamino)-N-cyclopropylmethoxy-3,4-difluorobenzamide; PXR, pregnane $\mathrm{X}$ receptor. 
signaling has been implicated in hepatic steatosis. Indeed, studies in transgenic mice have revealed involvement of PXR in hepatic lipogenesis and fatty acid oxidation (Nakamura et al., 2007; Zhou et al., 2008; He et al., 2013). Moreover, PXR was found to promote steatosis in cultured primary human hepatocytes (Bitter et al., 2015; Li et al., 2015). In addition, genetic polymorphisms in the PXR gene (NR1I2) are associated with disease severity in NAFLD (Sookoian et al., 2010). These findings offer an intriguing link between PXR signaling in the development of NAFLD and the observed reduction in CYP3A4 activity.

Fibroblast growth factor 21 (FGF21) is a hormone secreted largely by the liver that acts as a potent regulator of carbohydrate and lipid metabolism (Kharitonenkov et al., 2005). In NAFLD, both circulating FGF21 and hepatic FGF21 mRNA levels are elevated as a protective response to metabolic dysregulation (Li et al., 2010; Yilmaz et al., 2010). Indeed, pharmacological treatment with FGF21 reduces hepatic steatosis and weight, improves triglyceride and lipoprotein profiles, and increases insulin sensitivity in rodents and nonhuman primates (Kharitonenkov et al., 2007; Xu et al., 2009). Such beneficial metabolic actions are the motivation for the development of FGF21 mimetic drugs, which, in phase I studies, had favorable effects on serum cholesterol and triglycerides in humans with type 2 diabetes (Gaich et al., 2013; Dong et al., 2015). Given the diverse metabolic effects and upregulation in NAFLD, we explored whether FGF21 was a contributor to reduced CYP3A4 drug metabolism.
In this report, we demonstrate that hepatic CYP3A4 mRNA expression is downregulated by FGF21 through a receptormitogen-activated protein kinase (MAPK) pathway leading to reduced nuclear PXR localization and CYP3A4 gene transcription.

\section{Materials and Methods}

Human Tissue Samples. Studies were approved by the Human Subjects Research Ethics Board at the University of Western Ontario, and all study participants provided written informed consent. The study protocol conformed to the ethical guidelines of the 1975 Declaration of Helsinki. Liver biopsy samples and fasting plasma were collected from patients with biopsy-proven NAFLD as reported by Beaton et al. (2013). NAFLD disease staging into simple steatosis and NASH was defined using a histologic NAFLD activity score as described previously (Woolsey et al., 2015). Normal human liver samples were obtained through the Liver Tissue Cell Distribution System (Minneapolis, MN; funded by National Institutes of Health Contract \#N01-DK-7-0004/HHSN267200700004C). Livers were considered normal after histologic assessment for steatosis by Oil Red O staining. Plasma was obtained from normal healthy control subjects as detailed previously (Woolsey et al., 2016). Total RNA of normal human adult adipose tissue was purchased from Biochain (Newark, CA).

Plasmids. An in vivo, liver-targeted human FGF21 (hFGF21) expression plasmid was assembled using the $p L I V E$ vector (Mirius Bio, Madison, WI) similar to that previously reported by Gao et al. (2014). CYP3A4-XREM-Luc reporter plasmid was prepared as described previously (Tirona et al., 2003). An expression plasmid for human PXR (hPXR) fused to the carboxy terminus of enhanced green
Human
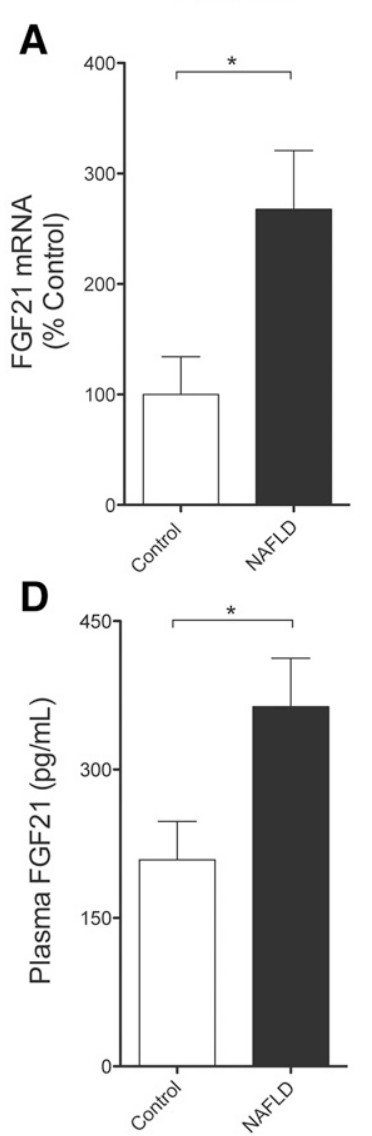

C57BL/6

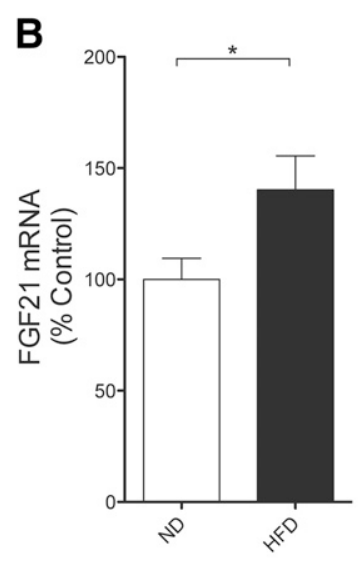

$\mathbf{E}$

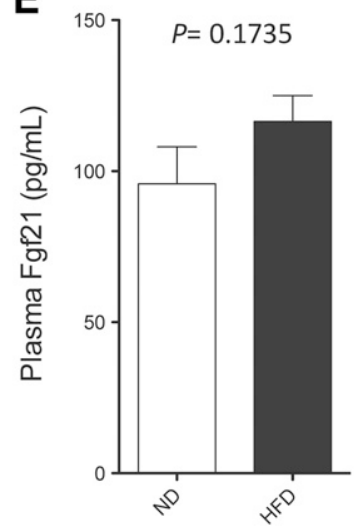

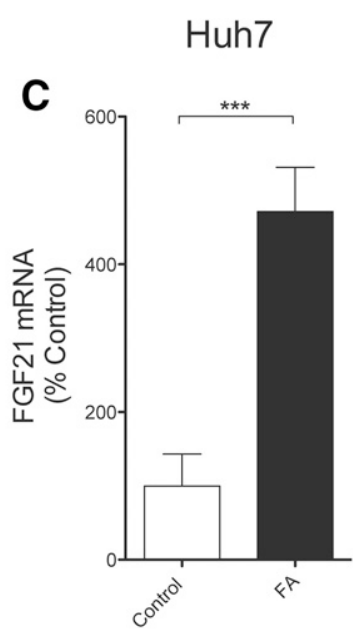

Fig. 1. FGF21 levels in NAFLD models. FGF21 mRNA expression in normal liver tissue $(n=8)$ and patients with NAFLD $(n=17)(\mathrm{A})$, female C57BL/6 mice given an HFD $(n=30)$ or ND $(n=30)$ for 4 weeks (B), or Huh7 cells 24 hours after treatment with $(n=$ $3)$ and without fatty acids (FA) $(n=3)$ (C). (D) Plasma FGF21 levels in healthy volunteers $(n=20)$ and NAFLD patients $(n=30)$. (E) Mouse FGF21 plasma concentrations in female C57BL/6 mice given an HFD $(n=20)$ or ND $(n=19)$ for 4 weeks. All plasma FGF21 levels were measured using a commercial ELISA kit, and expression levels were measured by quantitative PCR. Samples were analyzed in triplicate. Values are presented as the mean and standard error of the mean. ${ }^{* * *} P<0.0001 ;{ }^{*} P<0.05$ (twotailed $t$ test). 
fluorescence protein (GFP) was prepared by subcloning the PXR coding sequence into $p E G F P$-C1 (BD Biosciences, Palo Alto, CA).

Mouse Studies. Female, 5-week-old C57BL/6 mice (Jackson Laboratory, Bar Harbor, MA) were fed a normal diet (ND) (2018 Teklad Global 18\% protein rodent diet; Harlan Laboratories, Madison, WI) or a high-fat diet (HFD) (TD.88137 adjusted calories diet 42\% from fat; Harlan Laboratories) for 4 weeks to induce simple steatosis (Woolsey et al., 2015). Subsequently, PXR-GFP expression plasmid was transfected into the livers of mice by hydrodynamic, tail vein delivery $(25 \mu \mathrm{g}$ of DNA in $2 \mathrm{ml}$ of saline administered over 10 seconds). Twenty-four hours post-transfection, livers were extracted for gene expression, Western blot analysis, and epifluorescence microscopy. Female, 8-week-old C57BL/6 mice fed an ND were transfected with CYP3A4XREM-Luc or $p$ GL3 Basic (Promega, Madison, WI) together with a Renilla luciferase vector ( $2 \mu \mathrm{g}, p R L-C M V$; Promega) by hydrodynamic injection method. At 2 and 6 hours posthydrodynamic injection, mice were administered recombinant human FGF21 $(0.1 \mathrm{mg} / \mathrm{kg}$ total, intraperitoneal; R\&D Systems, Minneapolis, MN). Livers were extracted 24 hours later and analyzed for dual luciferase activity (Promega). Female, 8-week-old C57BL/6 mice on an ND were transfected with the PXR-GFP plasmid in combination with $p L I V E$-control or $p L I V E$ $h F G F 21$ expression plasmid together with CYP3A4-XREM-Luc or $p G L 3$ Basic plasmids by hydrodynamic injection. Twenty-four hours postinjection, livers were analyzed by dual luciferase assay and Western blot. These studies were approved by the University of Western Ontario Animal Use Subcommittee.

Plasma FGF21 Analysis. hFGF21 was measured by enzymelinked immunosorbent assay (ELISA, Human FGF21 Quantikine ELISA Kit; R\&D Systems) in fasting morning plasma samples collected from healthy normal subjects, NAFLD subjects, and mice overexpressing hFGF21. Mouse FGF21 plasma levels were measured by ELISA (Mouse Fgf-21 Quantikine ELISA Kit; R\&D Systems) in mice fed an HFD or ND.
Cell Culture Studies. Cultured Huh7 human hepatoma cells (Japan Health Sciences Foundation, Tokyo, Japan) were transfected with PXR-GFP and pLIVE-control or pLIVE-hFGF21 plasmids at 8090\% confluency using Huh7 GenTet transfection reagent (FroggaBio, Toronto, Canada). Twenty-four hours thereafter, cells were treated with recombinant human FGF21 (500 ng/ml; R\&D Systems) or rifampin ( $1 \mu \mathrm{M}$; Sigma-Aldrich, St. Louis, MO) for 24 hours. In some experiments, cells were pretreated for 1 hour with the MEK1 inhibitor PD184352 (10 $\mu \mathrm{M}$; Sigma-Aldrich) prior to FGF21 treatment. Experimental steatosis was induced by treatment with free fatty acids $(600 \mu \mathrm{M}$, oleate:palmitate, 2:1; Sigma-Aldrich) as described previously (Woolsey et al., 2015). CYP3A4 activity was determined by treating Huh7 cells with $1 \mu \mathrm{g} / \mathrm{ml}$ midazolam (Thermo Fisher Diagnostix, Mississauga, Canada) in Krebs-Henseleit bicarbonate buffer supplemented with $12.5 \mathrm{mM}$ HEPES and $5 \mathrm{mM}$ glucose. Cell culture medium was collected at 3 hours for analysis of 1-OH midazolam concentration by liquid chromatography-tandem mass spectrometry (Woolsey et al., 2016).

Gene Expression Analysis. RNA from human liver biopsies and mouse liver as well as Huh7 cells was extracted using TRIzol (Life Technologies, Carlsbad, CA) and reverse transcribed (MultiScribe; Applied Biosystems, Carlsbad, CA) with random hexamers. Relative mRNA expression of all genes was determined by SYBR green-based quantitative polymerase chain reaction (PCR) with normalization to $18 \mathrm{~S}$ ribosomal RNA by the Taqman method (Applied Biosystems). Primer sequences can be found in Suppplemental Table 1.

Western Blot Analysis. Liver homogenates prepared from C57BL/6 mice given an HFD or ND or transfected with $p L I V E$-control or $p L I V E$ $h F G F 21$ were analyzed by Western blot using anti-phospho-MAPK [extracellular signal-related kinase 1/2 (Erk1/2), Thr202/Tyr204; Cell Signaling Technology, Danvers, MA), total anti-p44/42 MAPK (Erk1/2; Cell Signaling Technology), or anti-FGF21 (R\&D Systems).

Epifluorescence Microscopy. Mouse livers transfected with the PXR-GFP expression plasmid were treated with $10 \%$ neutral formalin,

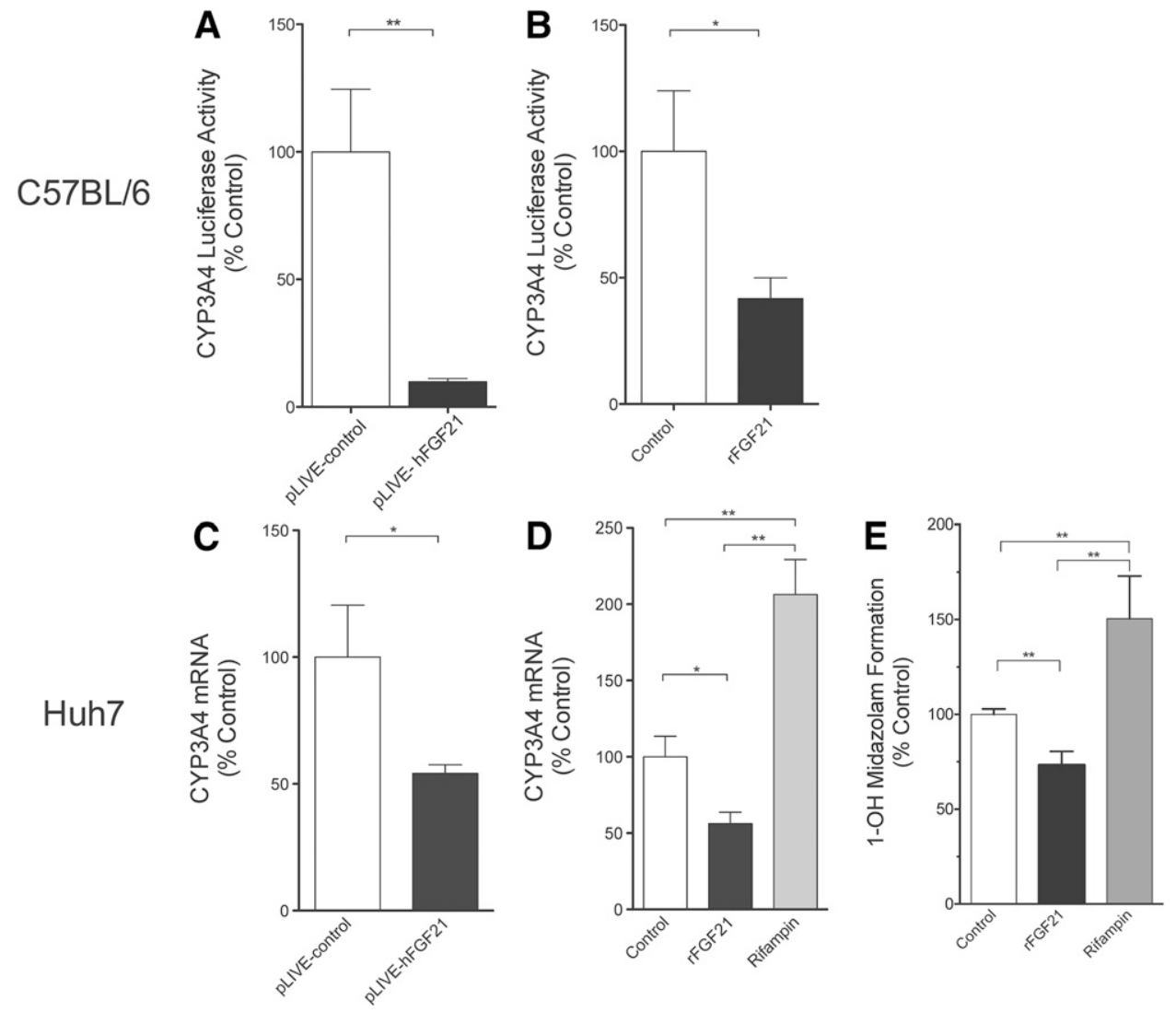

Fig. 2. Effect of FGF21 on CYP3A4 transcription and expression. C57BL/6 mice transfected with a CYP3A4 firefly luciferase reporter or promoterless reporter and pLIVE-control or $p L I V E-h F G F 21$ expression vectors, together with a Renilla luciferase reporter as transfection control. Hepatic CYP3A4 luciferase activities in C57BL/6 mice 24 hours after transfection with pLIVE-hFGF21 $(n=5)$ or pLIVEcontrol vector $(n=6)(\mathrm{A})$ and mice 24 hours after administration of recombinant human FGF21 (rFGF21; $0.1 \mathrm{mg} / \mathrm{kg}$ total, $n=$ 7) or saline $(n=6)(\mathrm{B})$. CYP3A4 mRNA expression in Huh7 cells 24 hours after transfection with $p L I V E$-control or $p L I V E$ hFGF21 $(n=3)(\mathrm{C})$, and treatment with or without recombinant human FGF21 $(500 \mathrm{ng} / \mathrm{ml})$ or rifampin $(1 \mu \mathrm{M})(n=4)(\mathrm{D})$. (E) CYP3A4 activity in Huh7 cells after 24-hour treatment with rFGF21 $(500 \mathrm{ng} / \mathrm{ml})$ or rifampin $(1 \mu \mathrm{M})$ as determined by metabolism of midazolam $(1 \mu \mathrm{g} / \mathrm{ml})$ to $1-\mathrm{OH}$ midazolam $(n=3)$. Control group $1-\mathrm{OH}$ midazolam formation rate was $1.9 \pm 9 \mathrm{ng} / \mathrm{h} /$ mg. ${ }^{*} * P<0.001 ; * P<0.05$ (two-tailed $t$ test). 
embedded in optimum cutting temperature compound, and cryosectioned. Huh7 cells grown on glass culture slides and transfected with PXR-GFP were fixed with ice-cold $70 \%$ methanol. Slides were mounted with VECTASHIELD with 4',6'-diamidino-2phenylindole (Vector Laboratories, Burlington, Canada) for epifluorescence microscopy analysis (Nikon Eclipse).

Chromatin Immunoprecipitation. Chromatin immunoprecipitation was performed on GFP-PXR transfected Huh7 cells according to the manufacturer's protocol (EZ ChIP; Millipore, Billerica, MA). DNA was pulled down with anti-GFP (Ab290; Abcam, Cambridge, MA) or control rabbit IgG (Cell Signaling Technology). SYBR green-based quantitative PCR (Applied Biosystems) was done with primers detailed in Supplemental Table 1.
Statistical Analyses. Values are expressed as the mean \pm S.E.M. Statistical significance was evaluated using an unpaired two-tailed $t$ test or one-way analysis of variance with Dunnett's test. Differences were considered significant at the $P<0.05$ level. Analysis was performed using Prism Version 5.0 (GraphPad Software, La Jolla, CA).

\section{Results}

Circulating and Hepatic FGF21 mRNA Levels Are Elevated in NAFLD. We previously reported that CYP3A4 mRNA levels were 67\% lower in NAFLD (simple steatosis and NASH) livers than controls (Woolsey et al., 2015). In the same
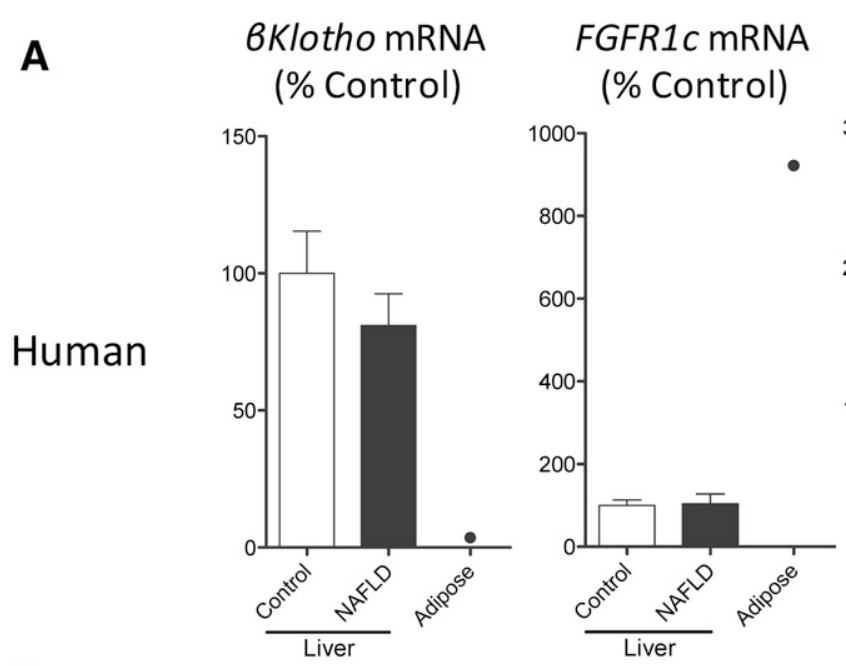

FGFR2c mRNA

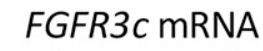

B
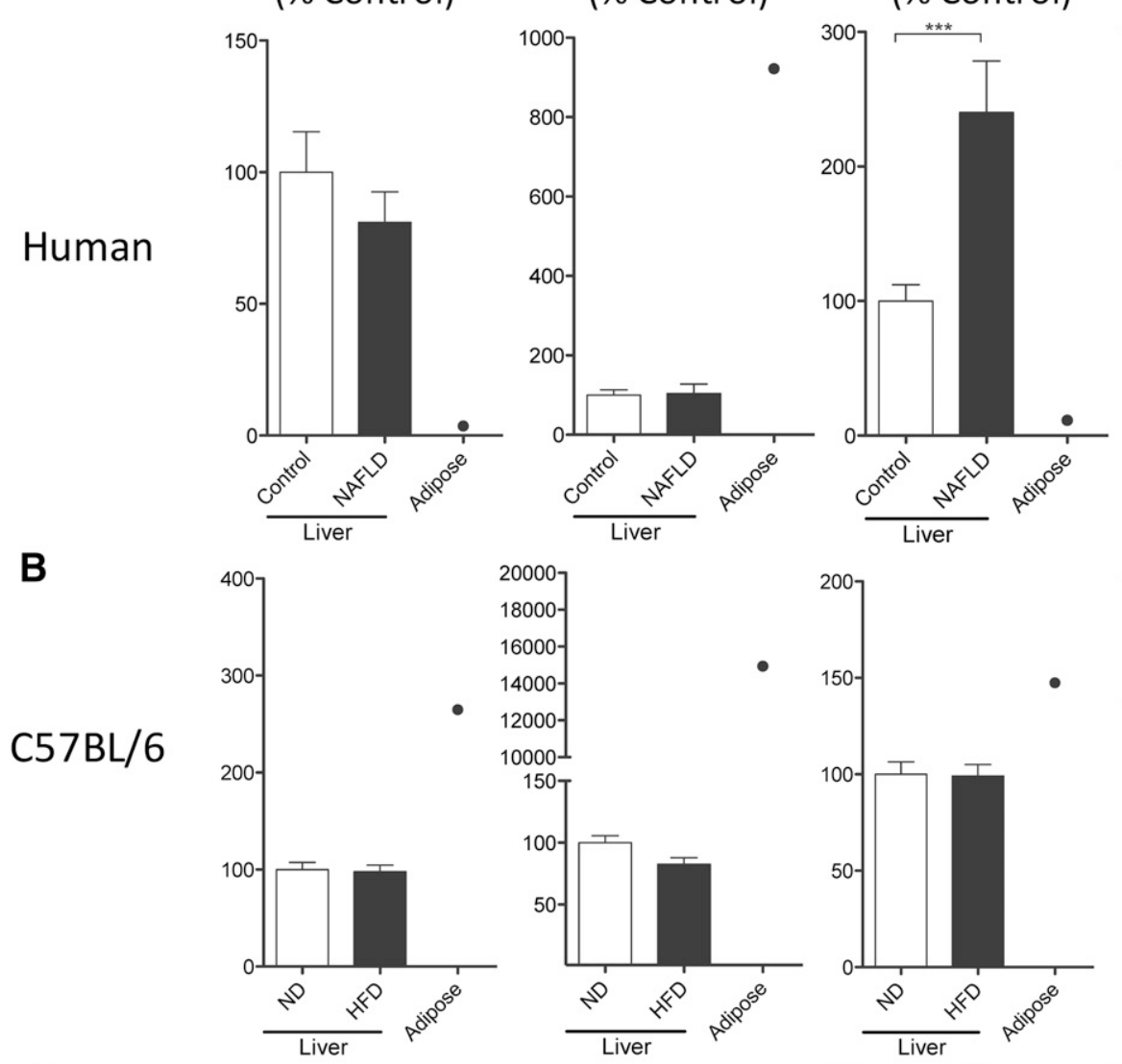

(\% Control)
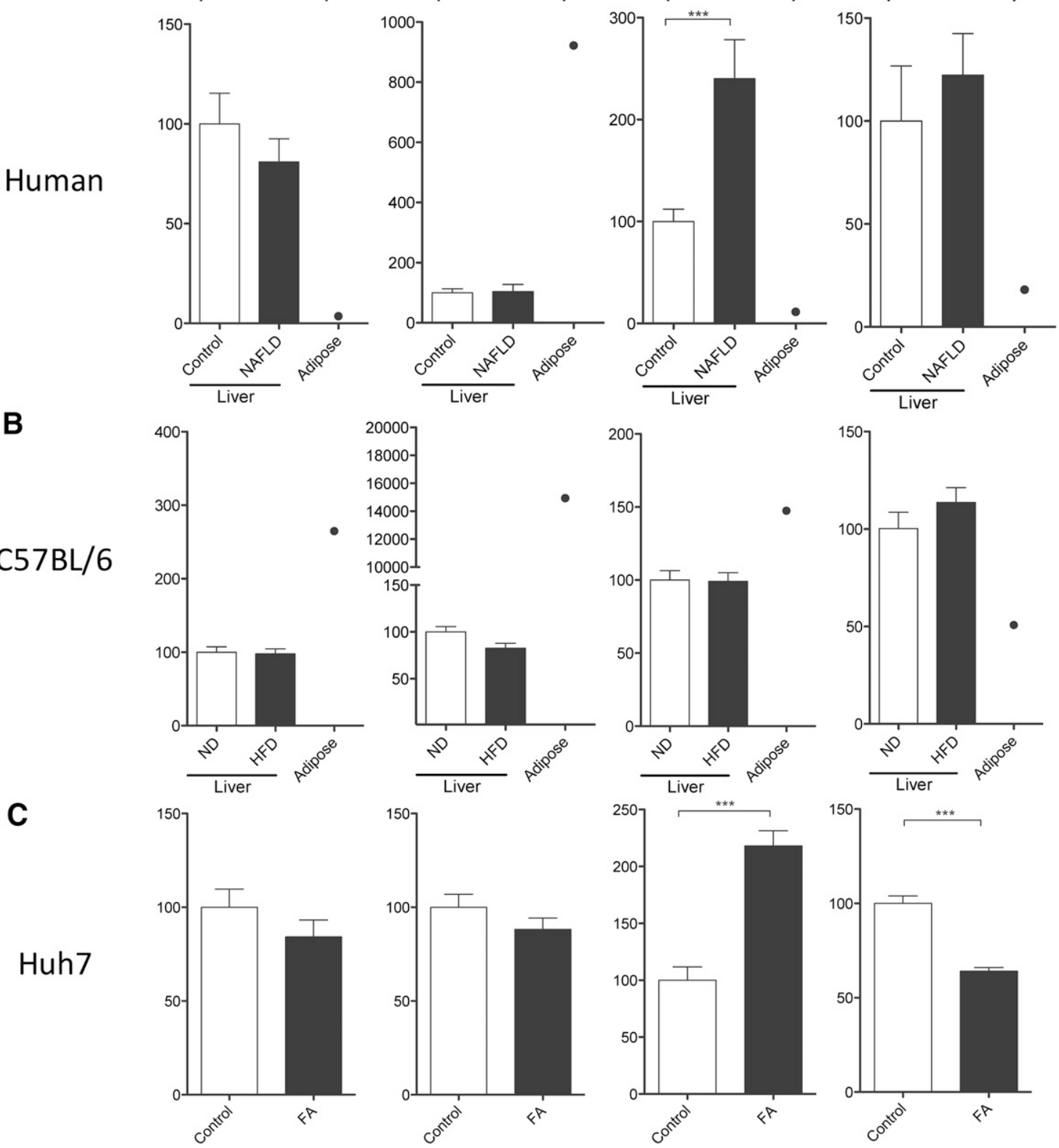

Fig. 3. FGFR and $\beta$ Klotho expression in human, mouse, and cellular NAFLD models. (A) Gene expression in normal control liver $(n=9)$, NAFLD liver $(n$ $=8)$, and normal adipose tissue $(n=1)$. (B) Female C57BL/6 mice given an ND $(n=6)$ and HFD $(n=6)$ for 4 weeks, and mouse adipose tissue $(n=1)$ (C) Control and fatty acid (FA)-treated Huh7 cells $(n=4)$. Expression levels were measured in triplicate using quantitative PCR and normalized by ribosomal $18 \mathrm{~S}$ expression. Values are presented as the mean and standard error of the mean. ${ }^{* * *} P<0.0001 ; * * P<0.001$; $* P<0.05$ (two-tailed $t$ test). 
biopsy samples ( $n=17$ ), FGF21 mRNA expression was $268 \pm$ $53 \%$ greater than in normal control livers $(n=8, P=0.039)$ (Fig. 1A). We further examined plasma collected from NAFLD subjects $(n=30)$ and healthy controls $(n=20)$ that was previously used to reveal lower CYP3A activity in NAFLD. Subjects with NAFLD had 1.7-fold higher plasma FGF21 concentrations in comparison with healthy controls $(P=$ 0.028) (Fig. 1D). In the earlier report, we also found that C57BL/6 mice with HFD-induced simple steatosis had reduced hepatic CYP3A4 luciferase reporter activity compared with those on an ND (Woolsey et al., 2015). Analysis of livers collected from these mice revealed a $140 \pm 15 \%$ higher Fgf21 mRNA expression with $\operatorname{HFD}(n=30)$ compared with $\mathrm{ND}(n=20$, $P=0.029$ ). There was a trend toward higher plasma FGF21 levels in HFD mice when compared with those receiving an $\mathrm{ND}(n=30$ and 19, respectively; $P=0.17$ ) (Fig. $1, \mathrm{~B}$ and $\mathrm{E}$ ). Furthermore, we previously reported that cultured Huh7 cells accumulate intracellular lipid droplets after fatty acid loading, and that CYP3A4 expression and activity are reduced in this cell culture model of NAFLD (Woolsey et al., 2015) (Fig. $3 \mathrm{C})$. In this in vitro model, we find $471 \pm 60 \%$ greater FGF21 mRNA expression in lipid-loaded Huh7 cells than control cells $(P=0.0001)$ (Fig. 1C). These results indicate an association between FGF21 expression and CYP3A4 activity in NAFLD.

FGF21 Administration and Hepatic FGF21 Overexpression Reduces CYP3A4 Expression In Vivo and In Vitro. We examined the effect of FGF21 on hepatic CYP3A4 reporter gene activity in $\mathrm{C57 \textrm {BL }} / 6$ mice. Mice were transfected with a human $F G F 21$ overexpression plasmid, $p L I V E-h F G F 21$, driven by a strong hepatocyte-specific $\alpha$-fetoprotein enhancer and albumin promoter. Mice acutely overexpressing human FGF21 ( $n=6$ ) had a significant 126-fold increase in plasma FGF21 levels in comparison with control mice $(n=4)$ (Supplemental Fig. 1A). On the basis of potential species-dependent CYP3A gene regulation, we delivered a human CYP3A4 luciferase reporter plasmid into mouse livers as a surrogate measure of gene transcription. We found that mice overexpressing human FGF21 $(n=5)$ had $90 \pm 1 \%$ lower CYP3A4 reporter activity ( $n=6, P=0.0089$ ) (Fig. $2 \mathrm{~A}$ ). In another experiment, female C57BL/6 mice were treated with recombinant human FGF21 $(n=7)$ or saline $(n=6)$ after hepatic transfection of the human CYP3A4 luciferase reporter plasmid. FGF21-treated mice had $58 \pm 8.5 \%$ lower CYP3A4 transcriptional activity compared with controls $(P=0.032)$ (Fig. $2 \mathrm{~B})$.

CYP3A4 is constitutively expressed in Huh7 cells with levels increasing with continued culture postconfluence (Sivertsson et al., 2010). We found measureable CYP3A4 expression and activity in Huh7 cells cultured 3 weeks postconfluence, but at low levels (Woolsey et al., 2015). By transient transfection of a functionally active, GFP-tagged PXR expression plasmid, we found significantly increased CYP3A4 expression and inducibility after treatment with the PXR-activating ligand rifampin, indicating that PXR expression is relatively reduced in Huh7 cells (Supplemental Fig. 2). For this reason, we performed all subsequent experiments in Huh7 cells with transient PXR transfection. Huh7 cells were transfected with pLIVE-hFGF21 to overexpress FGF21. In Huh7 cell lysates retrieved 24 hours after FGF21 transfection, FGF21 was clearly detected by Western blot, which contrasted with a lack of expression in control cells (Supplemental Fig. 1B). CYP3A4 mRNA expression was $46 \pm 3.6 \%$ lower in FGF21-overexpressing cells than controls (Fig. 2C). Huh7 cells treated with recombinant human
FGF21 had $44 \pm 8 \%$ lower $(P<0.05)$ CYP3A4 mRNA expression compared with control cells (Fig. 2D). For comparison, CYP3A4 mRNA expression was lower by $54 \pm 9 \%(P<0.05)$ after experimental steatosis with fatty acid treatment. CYP3A4 activity, as measured by $1-\mathrm{OH}$ midazolam formation after treatment with midazolam, was $27 \pm 8 \%$ lower $(P<0.01)$ in Huh7 cells treated with recombinant human FGF21. These findings demonstrate that FGF21 affects the expression and activity of $C Y P 3 A 4$.

Hepatic FGF21 Receptor Expression in NAFLD. FGF21 binds to activate cell surface FGF receptor 1c, 2c, or 3c isoforms (FGFR1c, FGFR2c, FGFR3c), which are in complex with the $\beta$ Klotho coreceptor (Kurosu et al., 2007), leading to activation of the MAPK cascade (Kurosu et al.,
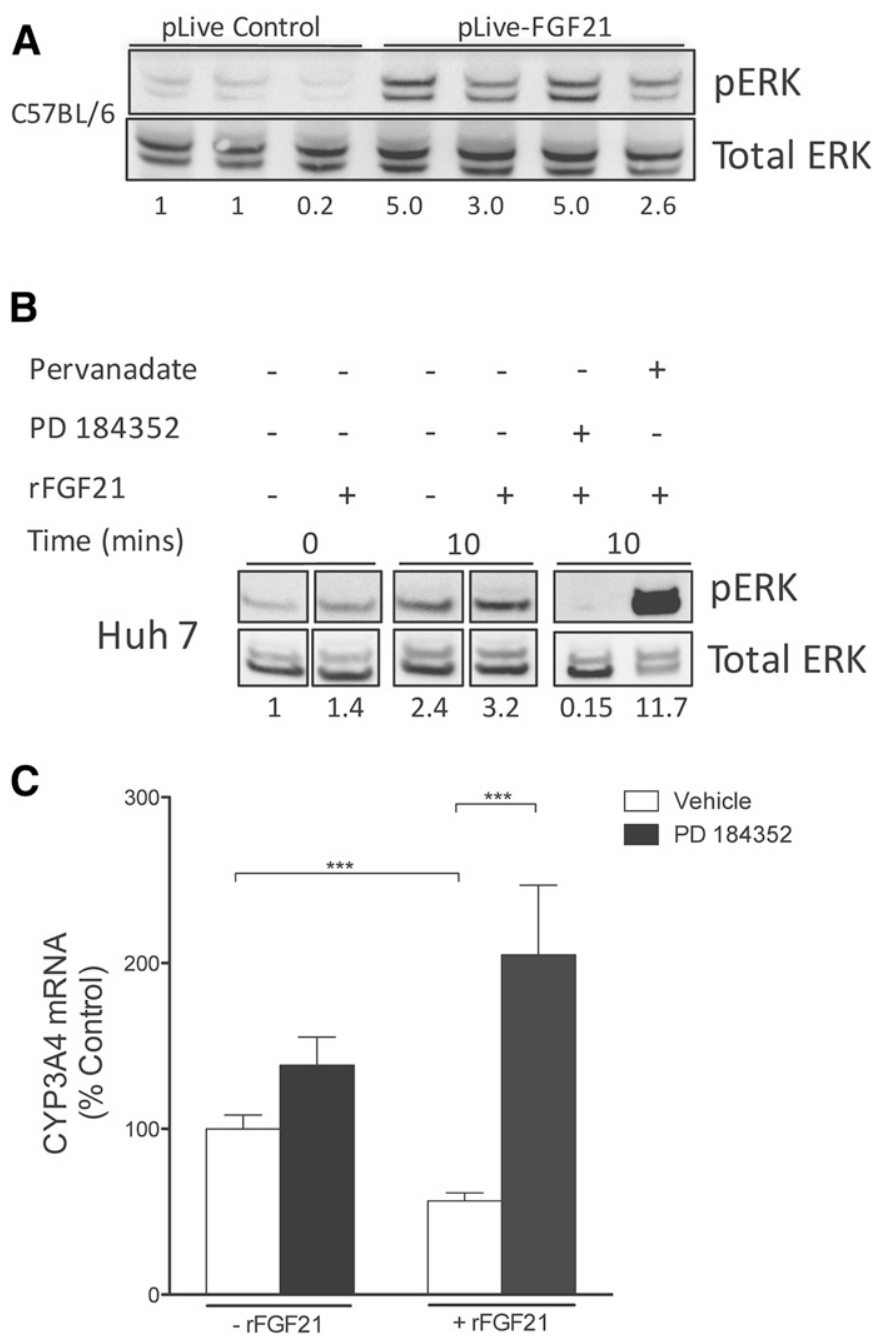

Fig. 4. FGF21-MAPK signaling in regulating CYP3A4 expression. (A) Western blot analysis of hepatic ERK1/2 phosphorylation in C57BL/6 mice 24 hours post-transfection with the pLIVE-control or pLIVE-hFGF21 expression plasmids. Numbers below each lane represent phosphorylated ERK (pERK)/total ERK ratios after densitometric analysis. (B) ERK1/2 phosphorylation in Huh7 cells before and after 10 minutes after treatment with recombinant human FGF21 (rFGF21; $500 \mathrm{ng} / \mathrm{ml}$ ) and after pretreatment with MEK inhibitor PD184352 $(10 \mu \mathrm{M})$. Huh7 cells treated with pervanadate were used as a positive control. Numbers below each lane represent pERK/total ERK ratios after densitometric analysis. (C) CYP3A4 mRNA expression in Huh7 cells 24 hours after treatment with recombinant human FGF21 (500 ng/ml) and/or PD184352 (10 $\mu \mathrm{M}$; $n=4)$. Values are presented as the mean and standard error of the mean. $* * P<0.001 ; * * * P<0.0001$ (two-tailed $t$ test). 
2007). Using isoform-specific quantitative PCR, we found that FGFR 1c expression was considerably lower in human and mouse livers compared with adipose tissue, an important target tissue (Fig. 3, A and B). However, FGFR2c and FGFR3c expression was greater in human liver than in fat, whereas these receptors were found at similar levels among mouse hepatic and adipose tissues (Fig. 3, A and B). BKlotho expression in human liver was greater than in adipose tissues; however, the opposite was found in mouse (Fig. 3, A and B). In NAFLD livers, there was increased FGFR2c expression but no differences in FGFR1c, FGFR3c, or $\beta$ Klotho when compared with control livers (Fig. 3A). FGFR1c and $\beta K$ lotho expression was unchanged with experimental steatosis in Huh7 cells; however, there was an increase and decrease in FGFR2c and FGFR3c, respectively (Fig. 3C). In mice, HFD-induced simple steatosis did not influence the expression of FGFRs and $\beta$ Klotho. These findings show that components of the FGF21 receptor are present in human NAFLD liver and experimental models.

Role of Canonical FGF21-MAPK Cascade in Regulating CYP3A4 Expression. In C57BL/6 mice, hepatic overexpression of human FGF21 resulted in activation of MAPK signaling as demonstrated by increased levels of phosphorylated ERK in liver (Fig. 4A). Treatment of cultured Huh7 cells with recombinant human FGF21 caused rapid ERK phosphorylation that was dramatically attenuated by pretreating cells with the MEK1 inhibitor, PD184352 (Fig. 4B). Importantly, the reduction of CYP3A4 mRNA expression by recombinant FGF21 treatment in Huh7 cells could be reversed by pharmacological MEK1 inhibition (Fig. 4C). These results indicate involvement of canonical MAPK signaling in the downregulation of CYP3A4 by FGF21 in liver.

Altered Subcellular PXR Localization in NAFLD and by FGF21. Transcriptional activation of PXR in the
A
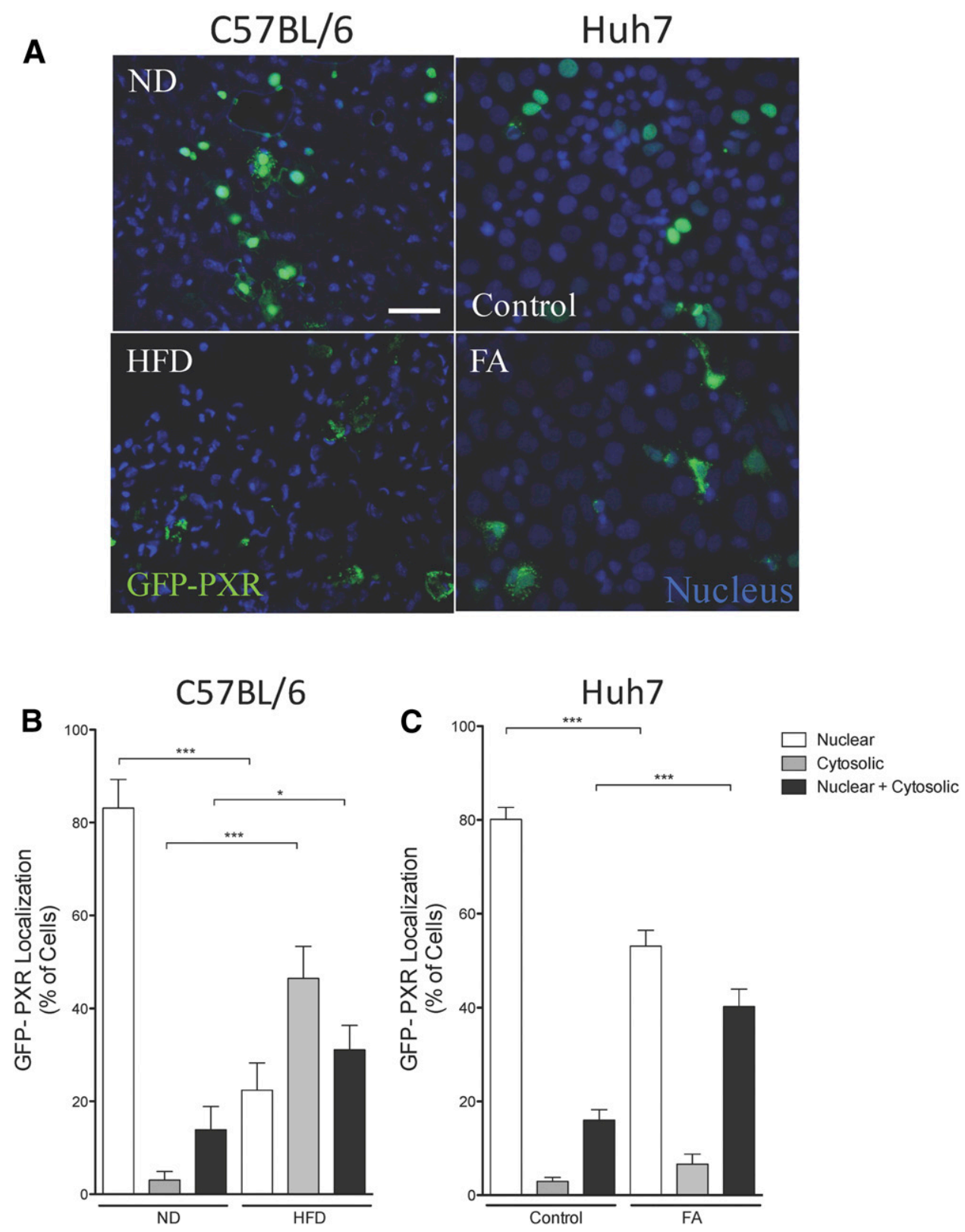

Fig. 5. Subcellular PXR localization in hepatic steatosis. (A) Immunofluorescence images of GFP-PXR-transfected C57BL/6 livers of mice fed an HFD or ND for 4 weeks and cultured Huh7 cells treated with or without fatty acids (FA) for 24 hours. Bar = $10 \mu \mathrm{m}$. Fraction of counted cells with nuclear, cytosolic, or nuclear and cytosolic localization after transfection with GFP-PXR in C57BL/6 mice fed an HFD $(n=3)$ or $\mathrm{ND}(n=3)(\mathrm{B})$ and (C) Huh7 treated with $(n=3)$ our without FA $(n=3) .{ }^{*} P<0.05$; $* * P<0.001 ; * * * P<0.0001$ (two-tailed $t$ test). 
regulation of CYP3A4 expression is thought to correlate with nuclear localization of the receptor (Pondugula et al., 2009). We examined the localization of GFP-human PXR (hPXR) in the mouse and cell NAFLD models. In C57BL/6 mice fed a ND, GFP-hPXR was localized mainly in hepatocyte nuclei (80\%), with fewer cells showing complete cytosolic or combined nuclear and cytosolic expression (Fig. 5A). HFD-induced steatosis resulted in a dramatic change in GFP-hPXR localization, shifting to less nuclear and greater cytosolic localization (Fig. 5A). Similarly, in cultured Huh7 cells where GFP-hPXR is largely nuclear in control cells, with experimental steatosis (fatty acid loading) there was a greater fraction of cells with cytosolic localization (Fig. 5B). We next examined the effect of FGF21 on the subcellular localization of GFPhPXR (Fig. 6A). Overexpression of hFGF21 in the livers of C57BL/6 mice resulted in a shift from largely nuclear PXR in

A
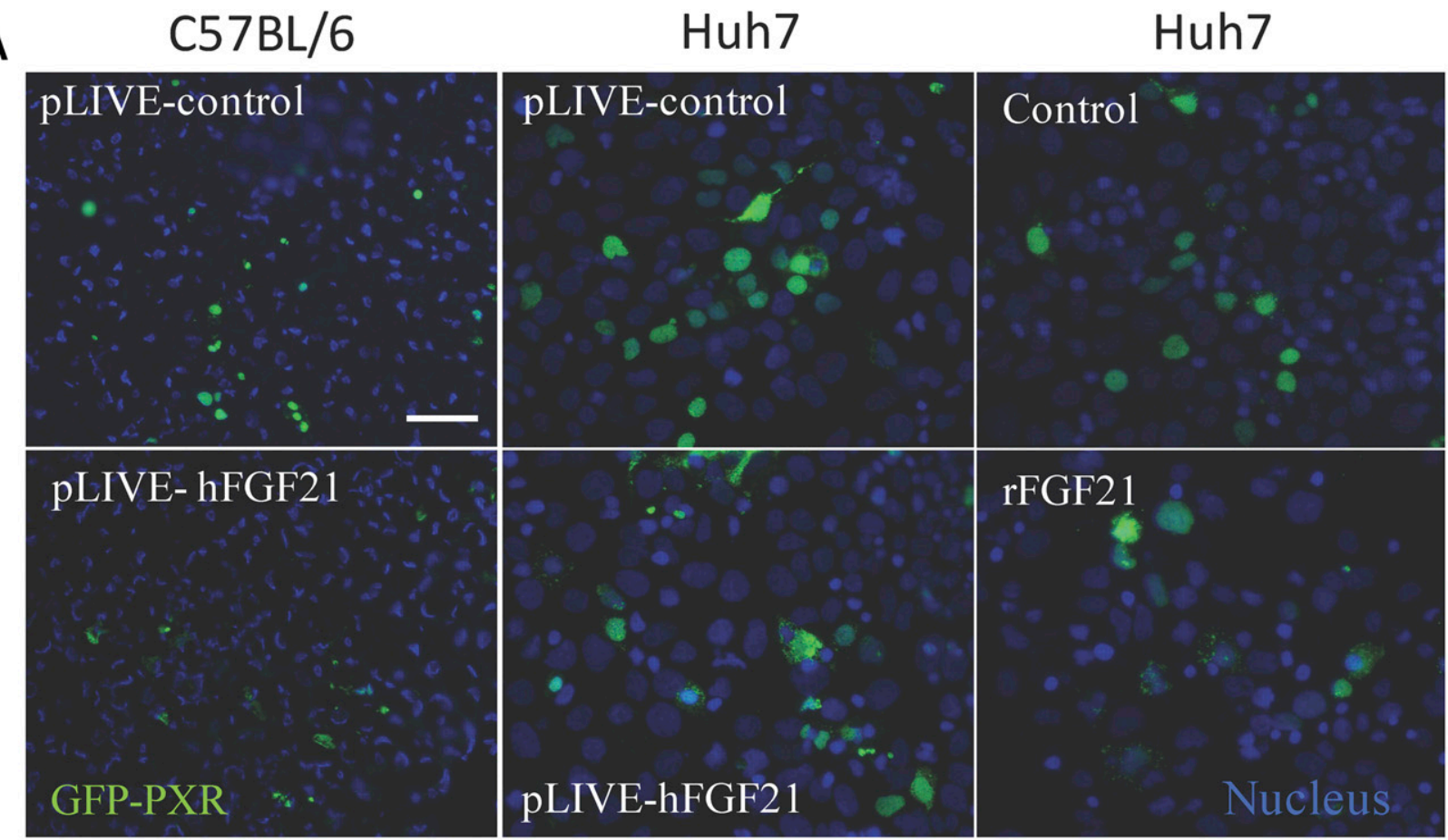

pLIVE-hFGF2 1

B

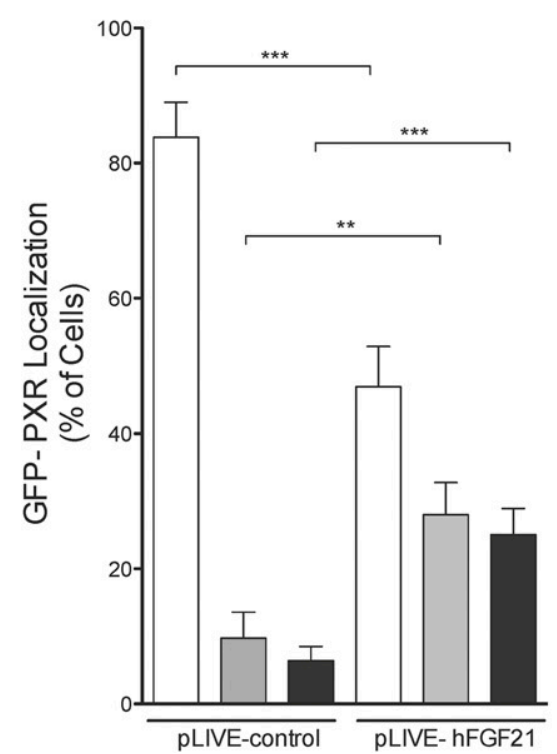

C

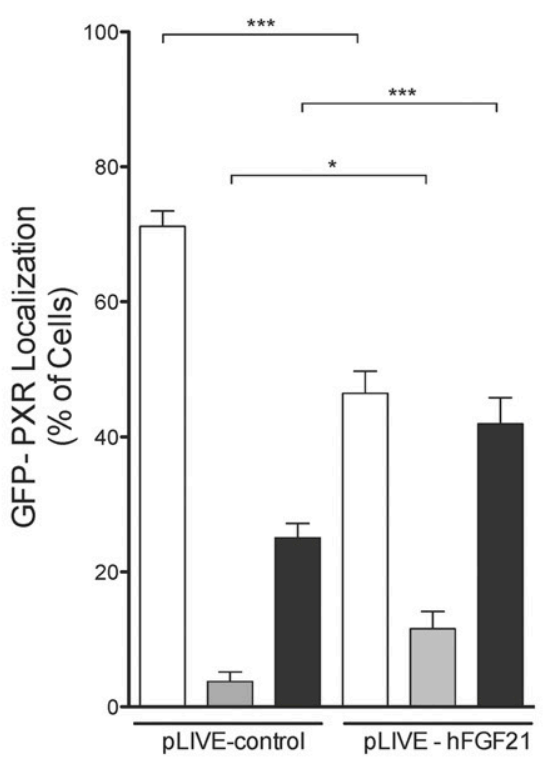

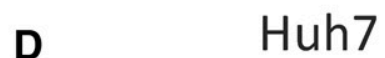

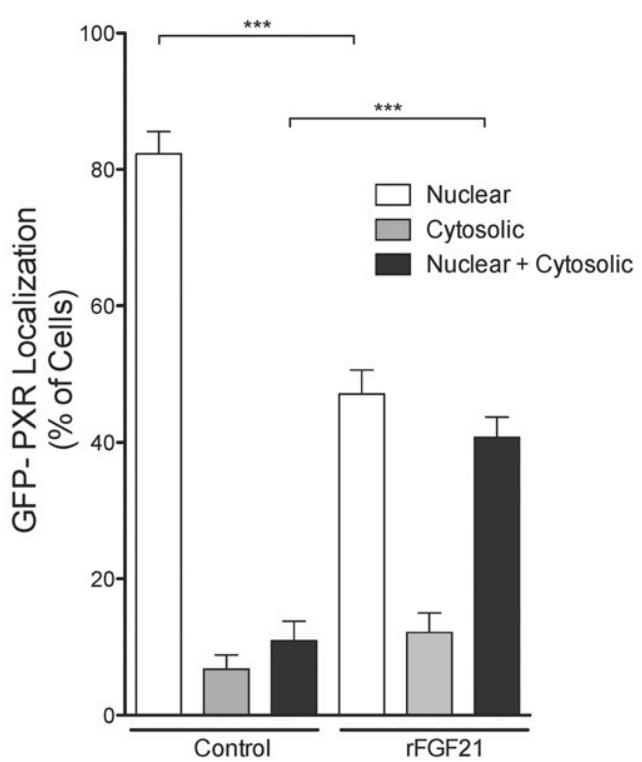

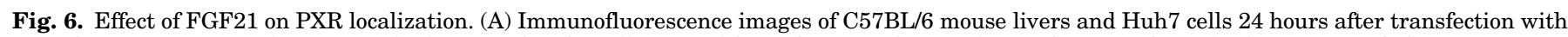

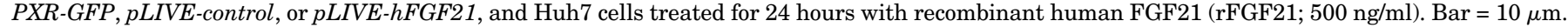

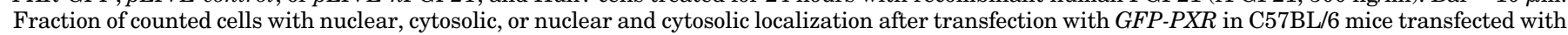

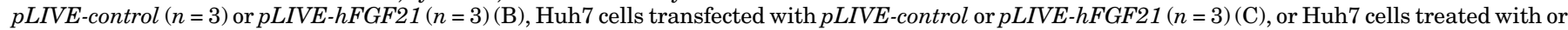
without human recombinant FGF21 $(n=3)(\mathrm{D}) .{ }^{*} P<0.05 ; * * P<0.001 ; * * * P<0.0001$ (two-tailed $t$ test). 
hepatocytes of control mice to a greater fraction of cells with cytosolic localization (Fig. 6B). In cultured Huh7 cells, FGF21 overexpression or treatment with recombinant FGF21 also reduced the number of cells with strict nuclear PXR localization while increasing the fraction of cells with some cytosolic expression (Fig. 6, C and D). Together, these data suggest that increased levels of FGF21 are associated with reduced nuclear PXR localization in NAFLD liver.

Decreased PXR Binding to CYP3A4 Promoter in Experimental Steatosis and FGF21 Treatment. Using chromatin immunoprecipitation and quantitative PCR, we examined GFP-hPXR binding to the known PXR binding site in the proximal CYP3A4 promoter in Huh7 cells under conditions of experimental steatosis and FGF21 treatment. FGF21 treatment reduced PXR binding to its response element in the CYP3A4 gene by $55 \pm 12 \%(P<0.001)$, whereas there was a trend toward decreased DNA binding with experimental steatosis (26\% lower, $P=0.17$ ) (Fig. 7). As a control, rifampin treatment increased PXR binding to the CYP3A4 promoter $(P=0.051)$ (Fig. 7). These data show that decreased PXR binding in the CYP3A4 promoter is associated with lower CYP3A4 mRNA expression during FGF21 treatment.

\section{Discussion}

We previously demonstrated that in vivo CYP3A activity in subjects with biopsy-proven NAFLD was reduced compared with healthy controls (Woolsey et al., 2015). Furthermore, we found that CYP3A4 expression was reduced in human NAFLD as well as mouse and cultured hepatoma cell models. In this report, we defined a potential mechanism involving induction of

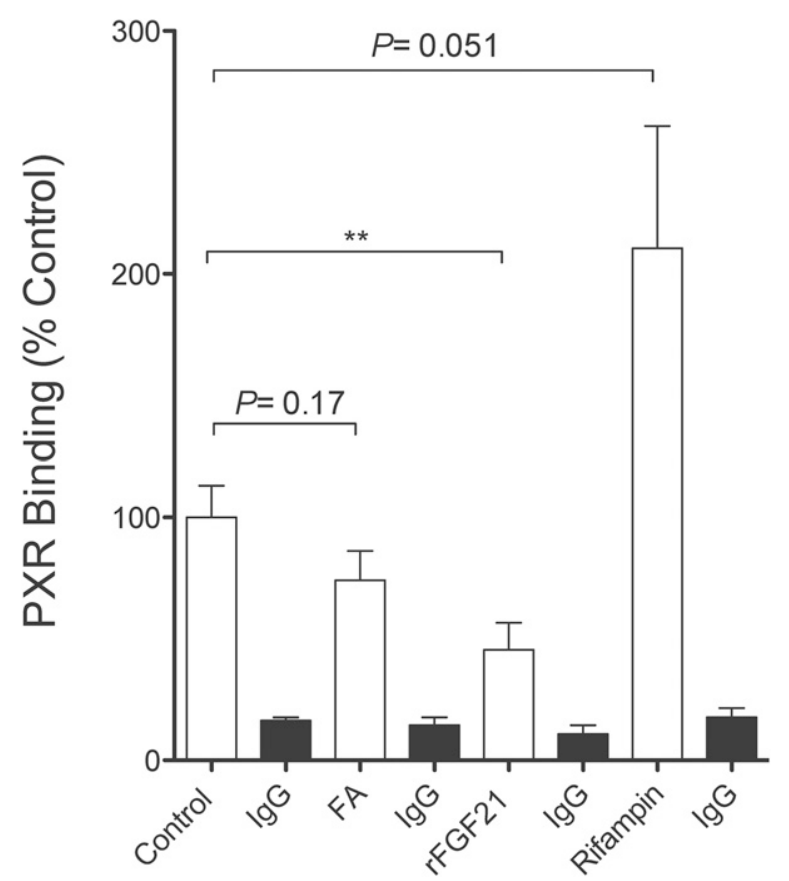

Fig. 7. $P X R$ binding to the CYP3A4 promoter. Chromatin immunoprecipitation and quantitative PCR analysis of PXR binding to the proximal promoter region of the CYP3A4 gene 24 hours after Huh7 cells were transfected with the PXR-GFP plasmid, then treated with fatty acids (FA; $600 \mu \mathrm{M})$, recombinant human FGF21 (rFGF21; $500 \mathrm{ng} / \mathrm{ml}$ ), and rifampin $(1 \mu \mathrm{M} ; n=4)$. All expression data were determined in triplicate and normalized to total DNA input. $* * P<0.001$ (two-tailed $t$ test).
FGF21 in NAFLD, leading to activation of hepatic MAPK signaling, altered PXR activation, and reduced transcription of the CYP3A4 gene. This mechanism parallels that found with downregulation of hepatic bile acid synthesis by intestinal exposure to bile acids through a FGF19-FGFR4-MAPK-CYP7A1 pathway (Inagaki et al., 2005; Song et al., 2009). Another similarity exists with hepatic epidermal growth factor receptor-MAPK-constitutive androstane receptor signaling in the regulation of drug-metabolizing $C Y P 2 B$ genes (Osabe and Negishi, 2011).

In the present FGF21-PXR-CYP3A4 pathway, the mechanisms by which ERK1/2 activation leads to altered subcellular localization of PXR remain to be determined. We found that chemical inhibition of MEK1 with PD184352 abrogated the repression of CYP3A4 expression by FGF21, implicating phospho-signaling in the mechanism. PXR is post-translationally modified by phosphorylation (Elias et al., 2014), which is considered to regulate PXR transcriptional activity and intracellular localization (Pondugula et al., 2009). Furthermore, PXR activation stimulates phosphorylation of heat shock protein $90 \beta$ (Kim et al., 2015), a known cytoplasmic PXR chaperone (Squires et al., 2004), leading to increased expression of target genes. Therefore, it is tempting to speculate that enhanced MAPK signaling by FGF21 affects phosphorylation of PXR or cochaperones (Squires et al., 2004; Ohno et al., 2014) to modulate subcellular localization of the nuclear receptor.

Although it is accepted that FGF21 acts on adipose, muscle, and brain to exert its metabolic effects, less in known about the liver as a direct target tissue for this hormone. Although many studies have shown beneficial effects of FGF21 on the liver metabolic functions, including the repression of lipogenesis, induction of fatty acid beta oxidation, as well as on gluconeogenesis, several studies were unable to recapitulate these effects in isolated perfused livers or primary rodent hepatocytes treated with FGF21 (Kurosu et al., 2007; Potthoff et al., 2009). These findings are consistent with the relative absence of FGFR1c receptors in adult mouse liver, despite abundantly expressed $\beta$ Klotho coreceptor (Fon Tacer et al., 2010). Furthermore, an FGFR1c$\beta$ Klotho bispecific agonistic antibody was able to activate adipose tissue ERK1/2 but not in liver (Kolumam et al., 2015). Thus, it is considered that several effects of FGF21 on glucose homeostasis, insulin sensitivity, and hepatic steatosis may occur indirectly through stimulation of adiponectin secretion in adipocytes (Lin et al., 2013) or by actions initiated in the central nervous system (Bookout et al., 2013). However, other studies demonstrated rapid hepatic ERK1/2 phosphorylation in mice after pharmacological administration of FGF21 and in isolated hepatocytes treated with FGF21, suggesting direct effects on the liver (Fisher et al., 2011; Jiang et al., 2014; Kolumam et al., 2015). Indeed, we observed enhanced ERK1/2 phosphorylation in mouse livers overexpressing FGF21 (Fig. 4A). Recently, a study in mice showed that the hepatic FGFR2- $\beta$ Klotho receptor complex is responsible for the reduction of liver cholesterol synthesis by FGF21 (Lin et al., 2015). We found that FGFR2c is expressed in liver and upregulated in human NAFLD (Fig. 3). Increased liver synthesis and higher plasma levels of FGF21 in NAFLD (Li et al., 2010; Yilmaz et al., 2010) may be an adaptive response that protects against hepatic lipotoxicity (Jiang et al., 2014). 
FGF21 expression is induced in liver by endoplasmic reticulum (ER) stress and the unfolded protein response (Schaap et al., 2013), the fatty acid-activated nuclear receptor, peroxisome proliferator-activated receptor $\alpha$ (Inagaki et al., 2007), glucocorticoid receptor (Patel et al., 2015), and arylhydrocarbon receptor (Lu et al., 2015). Given that ER stress response is commonly observed in human and animal models of NAFLD (Jiang et al., 2014), it is also likely that such a mechanism is responsible for FGF21 induction in our cohorts of human and mouse NAFLD livers and in steatotic Huh7 cells.

The regulatory pathway proposed here is expected to be one of several mechanisms involved in CYP3A4 regulation in NAFLD. For example, PXR expression is significantly decreased during ER stress (Vachirayonsti et al., 2015), and hepatic PXR protein levels were reduced in human NASH livers (Bitter et al., 2015). In our analysis, we did not find changes in PXR mRNA expression in human NAFLD biopsies or in the cell culture model of hepatic steatosis (Supplemental Fig. 3). Portal inflammation occurs in NAFLD livers in the early stages of simple steatosis and as disease progresses to NASH, resulting in increased levels of hepatic cytokines (Gadd et al., 2014). The degree of hepatic inflammation is likely to correspond to lower CYP3A4 expression given that inflammatory cytokines suppress drug-metabolizing enzyme gene expression (Abdel-Razzak et al., 1993) through mutual repression of PXR and nuclear factor $-\kappa \mathrm{B}$ transcriptional activities (Zhou et al., 2006). It is interesting, however, that we found a lack of downregulation in mRNA expression of other PXR target genes (ABCB1, CYP2C19, and UGT1A1) in human NAFLD livers (Supplemental Fig. 3).

There are differences in the regulation of CYP3A enzymes between alcoholic liver disease (ALD) and NAFLD. CYP3A expression and activity in liver samples of alcoholics are elevated (Niemelä et al., 2000; He et al., 2006), and ethanol induces CYP3A4 expression in cultured human hepatocytes (Kostrubsky et al., 1995). However, the in vivo activity of liver CYP3A4 as determined by intravenous midazolam pharmacokinetic analysis was unaffected by moderate alcohol consumption (Liangpunsakul et al., 2005). In mice, chronic ethanol intake increased hepatic Cyp3a11 levels through both increased expression and nuclear translocation of PXR (Je et al., 2015). Those findings in mouse ALD contrast with our results in mouse NAFLD, where we observed reduced nuclear PXR localization (Fig. 5) and modest reduction $(\sim 20 \%)$ in Cyp3a11 mRNA expression in liver (Woolsey et al., 2015). Since hepatic expression and plasma FGF21 levels are also elevated in a mouse model of ALD (Zhao et al., 2015), it would appear that FGF21 impacts CYP3A expression in ALD differently than in NAFLD.

Although we previously found that in vivo CYP3A4 activity was moderately reduced in biopsy-proven NAFLD patients using midazolam pharmacokinetics and endogenous plasma biomarker ( $4 \beta$-hydroxycholesterol) analyses (Woolsey et al., 2015), whether those with NAFLD require lower drug doses or are at greater risk for adverse drug events requires further investigation. In this regard, the development of methodologies such as magnetic resonance imaging and elastography (Dulai et al., 2016) that could replace the gold-standard liver biopsy for the diagnosis and staging of the disease will greatly facilitate future clinical studies aimed at examining the clinical relevance of lower CYP3A4 activity in the NAFLD population. Likewise, additional studies are necessary to confirm the role of FGF21 in regulating CYP3A4 in NAFLD. Use of cultured primary hepatocytes to directly study FGF21 regulation of CYP3A4 activity may be limited by rapid downregulation of the $\beta$ Klotho coreceptor, making this model unsuitable for longer-term studies (Fisher et al., 2011). Hence, in vivo evidence for reduced CYP3A4 activity after treatment with FGF21-mimetic drugs will be required to corroborate our findings.

In conclusion, we propose that CYP3A4 is downregulated in NAFLD, in part by a pathway involving induction of FGF21, activation of MAPK signaling cascade, a reduction in nuclear PXR, and subsequent diminution of PXR-mediated transactivation of the CYP3A4 gene. These findings have implications for dosing of CYP3A4-metabolized drugs in NAFLD and other conditions associated with elevated serum FGF21 (Gälman et al., 2008; Lin et al., 2011; Schoenberg et al., 2011; Dushay et al., 2014). Moreover, these results suggest that drug-drug interactions may occur with FGF21-mimetic drugs that are currently under development (Zhang and Li, 2015).

\section{Acknowledgments}

The authors thank Christopher J. Lemke for preparation of the pEGFP-hPXR expression plasmid.

\section{Authorship Contributions}

Participated in research design: Woolsey, Beaton, Pin, Adams, Kim, Tirona.

Conducted experiments: Woolsey, Beaton, Mansell, Leon-Ponte, Yu, Adams.

Contributed new reagents or analytic tools: Pin.

Performed data analysis: Woolsey, Adams, Tirona.

Wrote or contributed to the writing of the manuscript: Woosley, Beaton, Pin, Adams, Tirona.

\section{References}

Abdel-Razzak Z, Loyer P, Fautrel A, Gautier JC, Corcos L, Turlin B, Beaune P, and Guillouzo A (1993) Cytokines down-regulate expression of major cytochrome $\mathrm{P}-450$ enzymes in adult human hepatocytes in primary culture. Mol Pharmacol 44: $707-715$.

Angulo P (2002) Nonalcoholic fatty liver disease. N Engl J Med 346:1221-1231.

Beaton MD, Chakrabarti S, Levstik M, Speechley M, Marotta P, and Adams P (2013) Phase II clinical trial of phlebotomy for non-alcoholic fatty liver disease. Aliment Pharmacol Ther 37:720-729.

Bitter A, Rümmele P, Klein K, Kandel BA, Rieger JK, Nüssler AK, Zanger UM, Trauner M, Schwab M, and Burk O (2015) Pregnane X receptor activation and silencing promote steatosis of human hepatic cells by distinct lipogenic mechanisms. Arch Toxicol 89:2089-2103.

Bookout AL, de Groot MH, Owen BM, Lee S, Gautron L, Lawrence HL, Ding X, Elmquist JK, Takahashi JS, Mangelsdorf DJ, et al. (2013) FGF21 regulates metabolism and circadian behavior by acting on the nervous system. Nat Med 19: 1147-1152.

Browning JD, Szczepaniak LS, Dobbins R, Nuremberg P, Horton JD, Cohen JC, Grundy SM, and Hobbs HH (2004) Prevalence of hepatic steatosis in an urban population in the United States: impact of ethnicity. Hepatology 40:1387-1395.

Dong JQ, Rossulek M, Somayaji VR, Baltrukonis D, Liang Y, Hudson K, HernandezIllas M, and Calle RA (2015) Pharmacokinetics and pharmacodynamics of PF-05231023, a novel long-acting FGF21 mimetic, in a first-in-human study. $B r J$ Clin Pharmacol 80:1051-1063.

Dulai PS, Sirlin CB, and Loomba R (2016) MRI and MRE for non-invasive quantitative assessment of hepatic steatosis and fibrosis in NAFLD and NASH: Clinical trials to clinical practice. J HepatolS0168-8278(16)30267-7 [published ahead of print].

Dushay JR, Toschi E, Mitten EK, Fisher FM, Herman MA, and Maratos-Flier E (2014) Fructose ingestion acutely stimulates circulating FGF21 levels in humans. Mol Metab 4:51-57.

Elias A, High AA, Mishra A, Ong SS, Wu J, Peng J, and Chen T (2014) Identification and characterization of phosphorylation sites within the pregnane $\mathrm{X}$ receptor protein. Biochem Pharmacol 87:360-370.

Fisher FM, Estall JL, Adams AC, Antonellis PJ, Bina HA, Flier JS, Kharitonenkov A, Spiegelman BM, and Maratos-Flier E (2011) Integrated regulation of hepatic metabolism by fibroblast growth factor 21 (FGF21) in vivo. Endocrinology 152: 2996-3004.

Fon Tacer K, Bookout AL, Ding X, Kurosu H, John GB, Wang L, Goetz R, Mohammadi M, Kuro-o M, Mangelsdorf DJ, et al. (2010) Research resource: Comprehensive expression atlas of the fibroblast growth factor system in adult mouse. Mol Endocrinol 24:2050-2064. 
Gadd VL, Skoien R, Powell EE, Fagan KJ, Winterford C, Horsfall L, Irvine K, and Clouston $\mathrm{AD}$ (2014) The portal inflammatory infiltrate and ductular reaction in human nonalcoholic fatty liver disease. Hepatology 59:1393-1405.

Gaich G, Chien JY, Fu H, Glass LC, Deeg MA, Holland WL, Kharitonenkov A, Bumol T, Schilske HK, and Moller DE (2013) The effects of LY2405319, an FGF21 analog, in obese human subjects with type 2 diabetes. Cell Metab 18:333-340.

Gälman C, Lundåsen T, Kharitonenkov A, Bina HA, Eriksson M, Hafström I, Dahlin M, Amark P, Angelin B, and Rudling M (2008) The circulating metabolic regulator FGF21 is induced by prolonged fasting and PPARalpha activation in man. Cell Metab 8:169-174.

Gao M, Ma Y, Cui R, and Liu D (2014) Hydrodynamic delivery of FGF21 gene alleviates obesity and fatty liver in mice fed a high-fat diet. $J$ Control Release 185:1-11.

Guengerich FP (1999) Cytochrome P-450 3A4: regulation and role in drug metabolism. Annu Rev Pharmacol Toxicol 39:1-17.

He J, Gao J, Xu M, Ren S, Stefanovic-Racic M, O'Doherty RM, and Xie W (2013) PXR ablation alleviates diet-induced and genetic obesity and insulin resistance in mice. Diabetes 62:1876-1887.

He P, Court MH, Greenblatt DJ, and von Moltke LL (2006) Factors influencing midazolam hydroxylation activity in human liver microsomes. Drug Metab Dispos 34:1198-1207.

Inagaki T, Choi M, Moschetta A, Peng L, Cummins CL, McDonald JG, Luo G, Jones SA, Goodwin B, Richardson JA, et al. (2005) Fibroblast growth factor 15 functions as an enterohepatic signal to regulate bile acid homeostasis. Cell Metab 2:217-225.

Inagaki T, Dutchak P, Zhao G, Ding X, Gautron L, Parameswara V, Li Y, Goetz R Mohammadi M, Esser V, et al. (2007) Endocrine regulation of the fasting response by PPARalpha-mediated induction of fibroblast growth factor 21. Cell Metab 5:415-425.

Je YT, Sim WC, Kim DG, Jung BH, Shin HS, and Lee BH (2015) Expression of CYP3A in chronic ethanol-fed mice is mediated by endogenous pregnane $\mathrm{X}$ receptor ligands formed by enhanced cholesterol metabolism. Arch Toxicol 89:579-589.

Jiang S, Yan C, Fang QC, Shao ML, Zhang YL, Liu Y, Deng YP, Shan B, Liu JQ, Li HT, et al. (2014) Fibroblast growth factor 21 is regulated by the IRE1 $\alpha$-XBP1 branch of the unfolded protein response and counteracts endoplasmic reticulum stress-induced hepatic steatosis. J Biol Chem 289:29751-29765.

Kharitonenkov A, Shiyanova TL, Koester A, Ford AM, Micanovic R, Galbreath EJ, Sandusky GE, Hammond LJ, Moyers JS, Owens RA, et al. (2005) FGF-21 as a novel metabolic regulator. $J$ Clin Invest 115:1627-1635.

Kharitonenkov A, Wroblewski VJ, Koester A, Chen YF, Clutinger CK, Tigno XT, Hansen BC, Shanafelt AB, and Etgen GJ (2007) The metabolic state of diabetic monkeys is regulated by fibroblast growth factor-21. Endocrinology 148:774-781.

Kim SW, Hasanuzzaman M, Cho M, Heo YR, Ryu MJ, Ha NY, Park HJ, Park HY, and Shin JG (2015) Casein Kinase 2 (CK2)-mediated phosphorylation of Hsp90 $\beta$ as a novel mechanism of rifampin-induced MDR1 expression. J Biol Chem 290:17029-17040.

Kliewer SA, Moore JT, Wade L, Staudinger JL, Watson MA, Jones SA, McKee DD, Oliver BB, Willson TM, Zetterström RH, et al. (1998) An orphan nuclear receptor activated by pregnanes defines a novel steroid signaling pathway. Cell 92:73-82.

Kolumam G, Chen MZ, Tong R, Zavala-Solorio J, Kates L, van Bruggen N, Ross J, Wyatt SK, Gandham VD, Carano RA, et al. (2015) Sustained Brown Fat Stimulation and Insulin Sensitization by a Humanized Bispecific Antibody Agonist for Fibroblast Growth Factor Receptor 1/ßKlotho Complex. EBioMedicine 2:730-743.

Kostrubsky VE, Strom SC, Wood SG, Wrighton SA, Sinclair PR, and Sinclair JF (1995) Ethanol and isopentanol increase CYP3A and CYP2E in primary cultures of human hepatocytes. Arch Biochem Biophys 322:516-520.

Kurosu H, Choi M, Ogawa Y, Dickson AS, Goetz R, Eliseenkova AV, Mohammadi M, Rosenblatt KP, Kliewer SA, and Kuro-o M (2007) Tissue-specific expression of betaKlotho and fibroblast growth factor (FGF) receptor isoforms determines metabolic activity of FGF19 and FGF21. J Biol Chem 282:26687-26695.

Li H, Fang Q, Gao F, Fan J, Zhou J, Wang X, Zhang H, Pan X, Bao Y, Xiang K, et al (2010) Fibroblast growth factor 21 levels are increased in nonalcoholic fatty liver disease patients and are correlated with hepatic triglyceride. J Hepatol 53:934-940

Li L, Li H, Garzel B, Yang H, Sueyoshi T, Li Q, Shu Y, Zhang J, Hu B, Heyward S, et al. (2015) SLC13A5 is a novel transcriptional target of the pregnane $\mathrm{X}$ receptor and sensitizes drug-induced steatosis in human liver. Mol Pharmacol 87:674-682.

Liangpunsakul S, Kolwankar D, Pinto A, Gorski JC, Hall SD, and Chalasani N (2005) Activity of CYP2E1 and CYP3A enzymes in adults with moderate alcohol consumption: a comparison with nonalcoholics. Hepatology 41:1144-1150.

Lin Z, Pan X, Wu F, Ye D, Zhang Y, Wang Y, Jin L, Lian Q, Huang Y, Ding H, et al. (2015) Fibroblast growth factor 21 prevents atherosclerosis by suppression of hepatic sterol regulatory element-binding protein-2 and induction of adiponectin in mice. Circulation 131:1861-1871.

Lin Z, Tian H, Lam KS, Lin S, Hoo RC, Konishi M, Itoh N, Wang Y, Bornstein SR, Xu A, et al. (2013) Adiponectin mediates the metabolic effects of FGF21 on glucose homeostasis and insulin sensitivity in mice. Cell Metab 17:779-789.

Lin Z, Zhou Z, Liu Y, Gong Q, Yan X, Xiao J, Wang X, Lin S, Feng W, and Li X (2011) Circulating FGF21 levels are progressively increased from the early to end stages of chronic kidney diseases and are associated with renal function in Chinese. PLoS One 6:e18398.

Lu P, Yan J, Liu K, Garbacz WG, Wang P, Xu M, Ma X, and Xie W (2015) Activation of aryl hydrocarbon receptor dissociates fatty liver from insulin resistance by inducing fibroblast growth factor 21. Hepatology 61:1908-1919.

Marchesini G, Bugianesi E, Forlani G, Cerrelli F, Lenzi M, Manini R, Natale S, Vann E, Villanova N, Melchionda N, et al. (2003) Nonalcoholic fatty liver, steatohepatitis, and the metabolic syndrome. Hepatology 37:917-923.
Nakamura K, Moore R, Negishi M, and Sueyoshi T (2007) Nuclear pregnane X receptor cross-talk with FoxA2 to mediate drug-induced regulation of lipid metabolism in fasting mouse liver. $J$ Biol Chem 282:9768-9776.

Niemelä O, Parkkila S, Juvonen RO, Viitala K, Gelboin HV, and Pasanen M (2000) Cytochromes P450 2A6, 2E1, and 3A and production of protein-aldehyde adducts in the liver of patients with alcoholic and non-alcoholic liver diseases. J Hepatol 33:893-901.

Ohno M, Kanayama T, Moore R, Ray M, and Negishi M (2014) The roles of co-chaperone CCRP/DNAJC7 in Cyp2b10 gene activation and steatosis development in mouse livers. PLoS One 9:e115663.

Osabe M and Negishi M (2011) Active ERK1/2 protein interacts with the phosphorylated nuclear constitutive active/androstane receptor (CAR; NR1I3), repressing dephosphorylation and sequestering CAR in the cytoplasm. J Biol Chem 286: 35763-35769.

Patel R, Bookout AL, Magomedova L, Owen BM, Consiglio GP, Shimizu M, Zhang Y, Mangelsdorf DJ, Kliewer SA, and Cummins CL (2015) Glucocorticoids regulate the metabolic hormone FGF21 in a feed-forward loop. Mol Endocrinol 29:213-223.

Pondugula SR, Brimer-Cline C, Wu J, Schuetz EG, Tyagi RK, and Chen T (2009) A phosphomimetic mutation at threonine-57 abolishes transactivation activity and alters nuclear localization pattern of human pregnane x receptor. Drug Metab Dispos 37:719-730.

Potthoff MJ, Inagaki T, Satapati S, Ding X, He T, Goetz R, Mohammadi M, Finck BN Mangelsdorf DJ, Kliewer SA, et al. (2009) FGF21 induces PGC-1alpha and regulates carbohydrate and fatty acid metabolism during the adaptive starvation response. Proc Natl Acad Sci USA 106:10853-10858.

Schaap FG, Kremer AE, Lamers WH, Jansen PL, and Gaemers IC (2013) Fibroblast growth factor 21 is induced by endoplasmic reticulum stress. Biochimie 95:692-699.

Schoenberg KM, Giesy SL, Harvatine KJ, Waldron MR, Cheng C, Kharitonenkov A and Boisclair YR (2011) Plasma FGF21 is elevated by the intense lipid mobilization of lactation. Endocrinology 152:4652-4661.

Sivertsson L, Ek M, Darnell M, Edebert I, Ingelman-Sundberg M, and Neve EP (2010) CYP3A4 catalytic activity is induced in confluent Huh7 hepatoma cells. Drug Metab Dispos 38:995-1002.

Song KH, Li T, Owsley E, Strom S, and Chiang JY (2009) Bile acids activate fibroblast growth factor 19 signaling in human hepatocytes to inhibit cholesterol 7alpha-hydroxylase gene expression. Hepatology 49:297-305.

Sookoian S, Castaño GO, Burgueño AL, Gianotti TF, Rosselli MS, and Pirola CJ (2010) The nuclear receptor PXR gene variants are associated with liver injury in nonalcoholic fatty liver disease. Pharmacogenet Genomics 20:1-8.

Squires EJ, Sueyoshi T, and Negishi M (2004) Cytoplasmic localization of pregnane X receptor and ligand-dependent nuclear translocation in mouse liver. J Biol Chem 279:49307-49314.

Tirona RG, Lee W, Leake BF, Lan LB, Cline CB, Lamba V, Parviz F, Duncan SA, Inoue Y, Gonzalez FJ, et al. (2003) The orphan nuclear receptor HNF4alpha determines PXRand CAR-mediated xenobiotic induction of CYP3A4. Nat Med 9:220-224.

Vachirayonsti T, Ho KW, Yang D, and Yan B (2015) Suppression of the pregnane X receptor during endoplasmic reticulum stress is achieved by down-regulating hepatocyte nuclear factor- $4 \alpha$ and up-regulating liver-enriched inhibitory protein. Toxicol Sci 144:382-392.

Woolsey SJ, Beaton MD, Choi YH, Dresser GK, Gryn SE, Kim RB, and Tirona RG (2016) Relationships between endogenous plasma biomarkers of constitutive cytochrome P450 3A activity and single-time-point oral midazolam microdose phenotype in healthy subjects. Basic Clin Pharmacol Toxicol 118:284-291.

Woolsey SJ, Mansell SE, Kim RB, Tirona RG, and Beaton MD (2015) CYP3A Activity and Expression in Nonalcoholic Fatty Liver Disease. Drug Metab Dispos 43:1484-1490.

Xu J, Lloyd DJ, Hale C, Stanislaus S, Chen M, Sivits G, Vonderfecht S, Hecht R, L YS, Lindberg RA, et al. (2009) Fibroblast growth factor 21 reverses hepatic steatosis, increases energy expenditure, and improves insulin sensitivity in dietinduced obese mice. Diabetes 58:250-259

Yilmaz Y, Eren F, Yonal O, Kurt R, Aktas B, Celikel CA, Ozdogan O, Imeryuz N, Kalayci C, and Avsar E (2010) Increased serum FGF21 levels in patients with nonalcoholic fatty liver disease. Eur J Clin Invest 40:887-892.

Zhang $\mathrm{J}$ and $\mathrm{Li} \mathrm{Y} \mathrm{(2015)} \mathrm{Fibroblast} \mathrm{Growth} \mathrm{Factor} 21$ Analogs for Treating Metabolic Disorders. Front Endocrinol (Lausanne) 6:168.

Zhao C, Liu Y, Xiao J, Liu L, Chen S, Mohammadi M, McClain CJ, Li X, and Feng W (2015) FGF21 mediates alcohol-induced adipose tissue lipolysis by activation of systemic release of catecholamine in mice. J Lipid Res 56:1481-1491.

Zhou C, Tabb MM, Nelson EL, Grün F, Verma S, Sadatrafiei A, Lin M, Mallick S, Forman BM, Thummel KE, et al. (2006) Mutual repression between steroid and xenobiotic receptor and NF-kappaB signaling pathways links xenobiotic metabolism and inflammation. $J$ Clin Invest 116:2280-2289.

Zhou J, Febbraio M, Wada T, Zhai Y, Kuruba R, He J, Lee JH, Khadem S, Ren S, Li S, et al. (2008) Hepatic fatty acid transporter Cd36 is a common target of LXR, PXR, and PPARgamma in promoting steatosis. Gastroenterology 134:556-567.

Address correspondence to: Dr. Rommel G. Tirona, Departments of Physiology \& Pharmacology and Medicine, The University of Western Ontario, 339 Windermere Road, London, Ontario, Canada N6A 5A5. E-mail: rommel. tirona@schulich.uwo.ca 